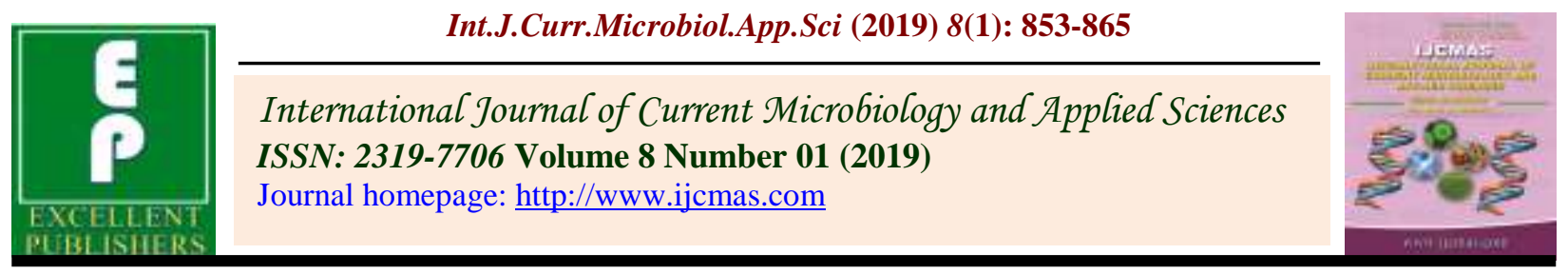

\title{
Kinetics of Nitrogen Mineralization as Influenced by Liming and Organic Amendments: A Laboratory Study
}

\author{
Lekhika Borgohain $^{1}{ }^{*}$, Danish Tamuly ${ }^{1}$, Niloy Borah ${ }^{1}$, Samiran Dutta ${ }^{1}$, Dhruba Jyoti \\ Nath $^{1}$, Ramani kanta Thakuria ${ }^{2}$, Karishma Borah ${ }^{3}$ and Sarat Shekhar Bora ${ }^{4}$ \\ ${ }^{1}$ Department of Soil Science, ${ }^{3}$ Department of Horticulture, ${ }^{4}$ Department of Agronomy, \\ Assam Agricultural University, Jorhat-13, Assam, India \\ ${ }^{2}$ AICRP on Water Management, Department of Agronomy, AAU, Jorhat-13, Assam, India
}

*Corresponding author

\section{Keywords}

Enriched compost,

FYM, Lime, N-

mineralization,

Kinetics

Article Info

Accepted:

07 December 2018

Available Online:

10 January 2019

\section{A B S T R A C T}

A laboratory incubation experiment was carried out to study the $\mathrm{N}$-mineralization and subsequent release of nitrogen from soil, treated with different levels of lime with organic amendments (FYM and enriched compost) over 100 days period. The experiment was laid out in a completely randomized design with 12 treatments replicated thrice. The data were fitted to first-order nitrogen mineralization model since it provided the best fit to the experimental data and also for its simplicity. Result revealed that release of Nitrate nitrogen $\left(\mathrm{NO}_{3}{ }^{-} \mathrm{N}\right)$ increased linearly with increasing lime dose and the incubation period whereas ammonical nitrogen $\left(\mathrm{NH}_{4}{ }^{+}-\mathrm{N}\right)$ increased exponentially with time and linearly with increasing lime dose. The values of mineralization rate constant $(k)$ varied from $2.80 \times 10^{-2}$ day $^{-1}$ to $3.60 \times 10^{-2}$ day $^{-1}$ in different treatments. The potential mineralizable nitrogen $\left(\mathrm{N}_{0}\right)$ varied from $200.98 \mathrm{mg} \mathrm{kg}^{-1}$ to $680.00 \mathrm{mg} \mathrm{kg}^{-1}$ across different treatments. The cumulative nitrogen content varied from $188.70 \mathrm{mg} \cdot \mathrm{kg}^{-1}$ to $661.50 \mathrm{mg} \cdot \mathrm{kg}^{-1}$ of soil. The highest rate of change of mineralizable nitrogen was found in treatment $\mathrm{T}_{6}$ (LR 100\% + EC @ 5ton ha ${ }^{-1}$ ) whereas lowest was found in control. It was found that the rate of change of mineralizable nitrogen $(d N / d t)$ decreased from the first day of incubation up to 100 days. The highest rate constant, cumulative nitrogen, potentially mineralizable nitrogen as well as mineral nitrogen were found to be significant and highest in treatment $\mathrm{T}_{6}$ consisting LR $100 \%+$ EC @ 5ton ha ${ }^{-1}$ than all other treatments.

\section{Introduction}

Nitrogen $(\mathrm{N})$ is the most important essential nutrient for plant growth. Over $90 \%$ of the total nitrogen $(\mathrm{N})$ in soils is in organic form. Although atmospheric $\mathrm{N}$ can contribute inorganic forms of $\mathrm{N}$ to soils, normally the amounts are small compared to crop's requirement. This organic $\mathrm{N}$ must first be mineralized to inorganic forms before it can become available to plants. The process of conversion of nitrogen from organic form to mineral forms by a wide variety of heterotrophic bacteria and fungi is called nitrogen mineralization. Plants mostly take up $\mathrm{N}$ as nitrate $\left(\mathrm{NO}_{3}{ }^{-}\right)$and ammonium $\left(\mathrm{NH}_{4}{ }^{+}\right)$. 
Nitrogen mineralization in soils is affected by various factors, including carbon (C) input rate (Matus et al., 2008), cropping system (Deng and Tabatabai, 2000), oxygen availability (Zibilske and Bradford, 2007), soil pH (Senwo and Tabatabai, 2005). In general, these are the same factors that affect microbial activity and plant growth. The effect of soil $\mathrm{pH}$ on $\mathrm{N}$ mineralization is obvious in most situations because maximum organisms participate in this process are available in neutral soil condition. Studies showed liming soils to greater $\mathrm{pH}$ values (from 4.9 to 6.7) had a great effect on $\mathrm{N}$ mineralization rates (Senwo and Tabatabai, 2005) because in some extremely acidic situations, mineralization is minimal. Numerous laboratory methods for estimating soil $\mathrm{N}$ availability have been proposed (Griffin, 2008). The most satisfactory methods currently available are biological methods that measure mineral $\mathrm{N}$ produced when the soil is incubated under aerobic or anaerobic conditions. The most widely used biological method for estimating soil $\mathrm{N}$ mineralization potential is the aerobic incubation method established by Stanford and Smith (1972). They predicted mineralizable soil $\mathrm{N}$ by a first-order exponential model obtained from a biologically based, long-term aerobic incubation method.

It is well established that soil acidity restricts nitrification in soils (Hu et al., 2014). The prevailing view is that soil acidity also restricts the rate at which organic $\mathrm{N}$ is converted to the inorganic form, and that liming produces a long-term increase in the rate of these conversions (Zhuang et al., 2016). Black (1986) suggested that when acid soils are limed, a portion of the soil organic matter becomes more susceptible to mineralization; but after this portion has been decomposed, mineralization returns to near its original level, despite altered composition of the soil microbial population. Liming increases soil $\mathrm{pH}$ to near neutrality where bacterial activity, particularly nitrifying bacteria, is greater. As a result, aerobic nitrogen (N) fixation and organic-matter decomposition process becomes faster, which hastens the mineralization process of organic matter and inorganic plant nutrients such as nitrogen $(\mathrm{N})$, phosphorus $(\mathrm{P})$, and sulphur $(\mathrm{S})$ in soil solution, where they become available to plants. The amelioration of soil acidity by liming and application of organic waste is expected to stimulate soil microbial activity, which may increase the release of $\mathrm{N}$ from the acid-soluble pool (Edmeades et al., 1981). It also stimulates the decomposition of organic matter and increase in availability of plant nutrients and microbial activity (Sims, 1996). But soil acidity may also be produced by the decomposition of plant residues or organic manure into organic acid. Therefore, the combined use of organic manures along with lime can ensure the sustainable crop yields to meet the food requirements of ever increasing population besides maintaining the soil health.

Hence, based on the above background, the following objectives were formulated

1. To study the effectiveness of co-application of lime and organic amendment on nitrogen mineralization kinetics

2. To evaluate efficient organic manure for $\mathrm{N}$ mineralization kinetics.

\section{Materials and Methods}

\section{Collection of soil sample}

A geo referenced acidic soil series i.e., Jorhat series $(13,326 \mathrm{ha})$ of Jorhat district based on established benchmark soil series of Assam (Vadivelu et al., 2004) was selected for this study and a composite soil sample was collected from five different sites, at a depth of $0-20 \mathrm{~cm}$. The site was located in the Upper Brahmaputra Valley zone of Assam (26 $77^{\circ}$ N 
and $94^{0} 34^{\prime} \mathrm{E}$ ), with sandy clay loam texture (sand $51.47 \%$, silt $25.92 \%$ and clay $22.62 \%$ ) and belongs to Typic Fluvaquents. Bulk soil sample was air dried, grounded, passed through $2 \mathrm{~mm}$ sieve and analysed for initial physical properties as per the standard procedures. Some selected properties of the experimental soil as measured by standard procedure were: bulk density $1.41 \mathrm{mg} \cdot \mathrm{m}^{-3}$, maximum water holding capacity $45.38 \%$, $\mathrm{pH}_{\mathrm{w}} 4.47$, organic carbon $0.88 \%$, CEC 7.53 meq. $100 \mathrm{gm}^{-1}$, available N $226.53 \mathrm{~kg} \cdot \mathrm{ha}^{-1}$, available $\mathrm{P} 14.26 \mathrm{~kg} \cdot \mathrm{ha}^{-1}$ and available $\mathrm{K}$ $198.83 \mathrm{~kg} \cdot \mathrm{ha}^{-1}$, respectively.

\section{Incubation experiments}

The collected soil sample was air dried, grounded and passed through a $5 \mathrm{~mm}$ sieve for the incubation study to determine the efficacy of liming and organic manure on $\mathrm{N}$ mineralization. Five hundred gram soil samples was subjected to different treatments where lime was applied to each soil in different combination with organic amendment (farm yard manure and enriched compost on air dry basis) in different combinations. The treatment combinations were $\mathrm{T}_{1}$ (Control); $\mathrm{T}_{2}$ (Lime $100 \% \mathrm{LR}$ ); $\mathrm{T}_{3}$ (FYM@ 5 t/ha*); $\mathrm{T}_{4}$ (Enriched compost@ 5 t/ha*); T $_{5}$ (Lime (100\% LR) + FYM@ 5 t/ha); $\mathrm{T}_{6}$ (Lime 100\% LR + Enriched compost@ 5 t/ha); $\mathrm{T}_{7}$ (Lime 50\% LR + FYM@ 5 t/ha); $\mathrm{T}_{8}$ (Lime 50\% LR + Enriched compost@ 5 t/ha); $\mathrm{T}_{9}$ (Lime 25\% LR + FYM@ 5 t/ha); $\mathrm{T}_{10}$ (Lime 25\% LR + Enriched compost@ 5 t/ha); $\mathrm{T}_{11}$ (Lime 10\% LR + FYM@ 5 t/ha) and $\mathrm{T}_{12}$ (Lime 10\% LR + Enriched compost@ 5 t/ha). The incubation experiment was laid out in a completely randomized design with 12 treatments including one control replicated thrice to study the mineralization kinetics of nitrogen as influenced by co-application of lime along with organic manure. Required quantities of lime was applied and mixed thoroughly with soil and incubate it for two weeks, after which required amount of FYM and enriched compost (EC) were thoroughly mixed with soil samples. The samples were then transferred to plastic container having $1000 \mathrm{ml}$ capacity and incubated for 100 days under room temperature. The moisture of treated samples was maintained at field capacity throughout the incubation period. The water content in the treatment was maintained by adding distilled water to the same level of water content of the soil. Soil samples were drawn at $0,20,40,60,80$ and 100 days and analysed for ammonical nitrogen $\left(\mathrm{NH}_{4}{ }^{+} \mathrm{N}\right)$ and nitrate nitrogen $\left(\mathrm{NO}_{3}{ }^{-} \mathrm{N}\right)$ by colorimetric method (Onken and Sunderman, 1977).

\section{Determination of nitrogen-mineralization kinetics}

The soil was extracted with $1 \mathrm{~N} \mathrm{Na}_{2} \mathrm{SO}_{4}$ phenylmercuric acetate and $\mathrm{NH}_{4}{ }^{+}-\mathrm{N}$ and $\mathrm{NO}_{3}{ }^{-}$ $\mathrm{N}$ in the solution was estimated colorimetrically (Onken and Sunderman, 1977).

To study the nitrogen mineralization kinetics and rate of change of mineralizable nitrogen, data were fitted to the widely used first order exponential equation (Stanford and Smith, 1972) as mentioned below

\section{Mineralized nitrogen $\left(\mathbf{N}_{\min }\right)=\mathbf{N}_{0}\left(1-\mathrm{e}^{-k t}\right)$}

\section{Rate of change of mineralizable nitrogen} $(\mathrm{dN} / \mathrm{dt})=\left(\mathrm{N}_{0} \cdot k\right) \cdot \mathrm{e}^{-k \mathrm{t}}$

Where, $\mathrm{N}_{\min }$ is the cumulative mineralized nitrogen at any specific time ' $t$ ' (day); $k$ is the first order rate constant $\left(\right.$ day $\left.^{-1}\right)$. The $\mathrm{N}_{0}$ is the potentially mineralizable $\mathrm{N}$.

Values of $\mathrm{N}_{0}$ and $\mathrm{k}$ were calculated by non linear least square regression analysis with the help of 'solver parameters' in WINDOW based MSEXCEL program. 


\section{Results and Discussion}

\section{Changes in mineral- $\mathbf{N}$ during incubation}

Release of Ammonical nitrogen $\left(\mathrm{NH}_{4}{ }^{+}-\mathrm{N}\right)$ and Nitrate nitrogen $\left(\mathrm{NO}_{3} \mathrm{~N}\right)$ :

Data pertaining to the release of $\mathrm{NH}_{4}{ }^{+}-\mathrm{N}$ and $\mathrm{NO}_{3}{ }^{-}-\mathrm{N}$ during 100 days of incubation as influenced by different doses of lime and organics are presented in table 1 (Fig. 1 and 2). Results revealed that significant increase in release of $\mathrm{NH}_{4}{ }^{+}-\mathrm{N}$ as well as $\mathrm{NO}_{3}{ }^{-} \mathrm{N}$ in soil occurred due to application of both organics, i.e., farm yard manure (FYM) and Enriched compost (EC), with different doses of lime over untreated control. Maximum release of $\mathrm{NH}_{4}{ }^{+}-\mathrm{N}$ was obtained with $\mathrm{T}_{5}$ treatment whereas Maximum release of $\mathrm{NO}_{3}^{-}-\mathrm{N}$ was obtained with $\mathrm{T}_{6}$ treatment. Treatment receiving enriched compost with $100 \%$ lime rate maintained higher amount of mineral nitrogen than other treatments. With increasing lime amount, a significant increase in the rate of release of $\mathrm{NH}_{4}{ }^{+}-\mathrm{N}$ as well as $\mathrm{NO}_{3}{ }^{-}-\mathrm{N}$ was found. During first 20 days of incubation, the release rate of $\mathrm{NH}_{4}{ }^{+}-\mathrm{N}$ was gradual, then it increased and reached its maxima at around 60 days, after which it decreased sharply. In case of $\mathrm{NO}_{3}{ }^{-} \mathrm{N}$, it was observed that during first 40 days of incubation the release was slow, and then it increased at a considerably higher rate till 80 days and thereafter maintained a slower rate of release. Studies have indicated that microorganism prefer $\mathrm{NH}_{4}{ }^{+}-\mathrm{N}$ for their growth and utilize $\mathrm{NO}_{3}{ }^{-}-\mathrm{N}$ when $\mathrm{NH}_{4}{ }^{+}-\mathrm{N}$ content is lower than $1 \mu \mathrm{g} \mathrm{N} \mathrm{g}{ }^{-1}$ soil. The initial slow rate of release of mineral $\mathrm{N}$ from organics with different dose of lime treated soil might be attributed to increased microbial activity. The microbes immobilized readily available $\mathrm{N}$ in to their biomass, which are subsequently released upon its decomposition. Under this condition, cumulative release of $\mathrm{NH}_{4}{ }^{+}-\mathrm{N}$ increased few days after incubation due to the addition of manure (FYM and EC). This may be attributed to rapid decomposition of easily decomposable $\mathrm{N}$-containing organic substances. The decomposition was carried out by microbes present in soil treated with organic manure and lime. Decrease in $\mathrm{NH}_{4}{ }^{+}-\mathrm{N}$ concentration was observed due to conversion of $\mathrm{NH}_{4}{ }^{+}-\mathrm{N}$ to $\mathrm{NO}_{3}{ }^{-} \mathrm{N}$ (Murugan and Swarnam, 2013). Higher release of mineral N from the soil treated with Enriched compost and $100 \%$ lime, might be due to the fact that with application of EC with high dose lime, the $\mathrm{C}: \mathrm{N}$ ratio narrowed down then that of soil treated with FYM and EC with low dose of lime (Patil, 1990). During the mineralization process ammonium was first released into the soil on which the nitrifying bacteria acted and oxidized it into nitrate form (Power and Papendick, 1985). By 60 days of incubation, the easily decomposable source of $\mathrm{N}$ was exhausted and the rate of release of $\mathrm{NH}_{4}{ }^{+} \mathrm{N}$ decreased and previously released $\mathrm{NH}_{4}{ }^{+} \mathrm{N}$ continued to convert to $\mathrm{NO}_{3}^{-}-\mathrm{N}$; thus cumulative amount of $\mathrm{NH}_{4}{ }^{+}-\mathrm{N}$ decreased while that of $\mathrm{NO}_{3}{ }^{-} \mathrm{N}$ increased. The rate of release of $\mathrm{NH}_{4}{ }^{+}-\mathrm{N}$ as well as $\mathrm{NO}_{3}{ }^{-}-\mathrm{N}$ was lower during the first 20 days of incubation, thereafter it increased and cumulative release of both was maximum at around 100 days of incubation.

\section{Nitrogen mineralization constants}

Mineralization data showed that the values of mineralization rate constant $(k)$ varied from $2.80 \times 10^{-2}$ to $3.60 \times 10^{-2}$ day $^{-1}$ in different treatments (Table 2). Correlation coefficients $\left(\mathrm{R}^{2}\right)$ values were also determined to validate the $\mathrm{N}$ mineralization data to fit well or not to the exponential equation.

It is hypothesized that higher value of rate constant $(k)$ indicates higher rate of release of available $\mathrm{N}$, but the duration of release of $\mathrm{N}$ is less. While higher potential mineralizable nitrogen $\left(\mathrm{N}_{0}\right)$ content indicates that both the 
rate constant as well as the duration of release may be higher (Biswas et al., 2017). So for clear understanding rate constant per unit potential mineralizable nitrogen $\left(k / \mathrm{N}_{0}\right)$ i.e. absolute rate constant $\left(k_{\mathrm{a}}\right)$ was calculated. The results indicated that with increased dose of lime, the duration of supply of available $\mathrm{N}$ increased.

Cumulative $\mathrm{N}$ mineralization in different treatments during 100 days of incubation ranged from 188.70 to $661.50 \mathrm{mg}{\mathrm{N} . \mathrm{kg}^{-1}}^{-}$ (Table 2). The time course of rate of change of nitrogen mineralization in different treatments showed that mineralization was faster during initial days of incubation followed by a relatively slower rate subsequently.

In most of the soils, more than half of the total $\mathrm{N}$ mineralization (100 days) had occurred by 50 days of incubation, whereas the remaining occurred in subsequent 50 days. This suggested that the initial rapid phase of mineralization was from an easily decomposable pool of organic matter whereas the later phase was from a recalcitrant fraction.

The mineralization rate also increased with increasing lime dose along with organics over control. Maximum mineralization rate was observed under treatment containing LR 100\% + EC@ @ ton ha ${ }^{-1}\left(\mathrm{~T}_{6}\right)$ whereas lowest in control. It might be due to increased rate of lime application with organics which in turn, increased the amount of $\mathrm{N}$ in soil as well as the microbial activity that had caused the slow and long duration $\mathrm{N}$ release through immobilization and mineralization processes.

The rate of change of mineralizable nitrogen $(d N / d t)$ decreases from the first incubation period till 100 days (Table 3 and Fig. 3) which is due to rapid decomposition of easily decomposable $\mathrm{N}$-containing organic substances by microorganisms in the earlier period (Gonzalez-Prieto et al., 1995).

\section{Soil properties before and after incubation of soil for estimating $\mathrm{N}$-mineralization}

Results of incubation study carried out in vegetable growing soil of Jorhat series showed an interesting pattern of change in soil $\mathrm{pH}$, organic carbon and available nutrients. Results presented in Table 4 shows the effect of compost with different doses of lime application on the soil $\mathrm{pH}$ after the incubation period.

The soil organic carbon content increase with increasing lime application. However different type of organic manures may also play a significant role. The treatments containing enriched compost (EC) had higher organic carbon content than treatment containing farm yard manure (FYM) at same level of lime dose. It might be due to difference in nutrient content in the manures (Bartholomew et al., 2011). The rapid build up of organic carbon in the soil might be due to action of mineralization and slow release of $\mathrm{N}$ and fixation and accumulation of organic $\mathrm{N}$ in the soil.

The buildup of organic carbon helps in retention of soil moisture and acts as buffer to the soil and also increases the infiltration rate. From the present investigation it was found that hundred per cent of recommended lime dose application had a negative impact on organic carbon whereas twenty five per cent of recommended lime dose with enriched compost had the highest OC content. The reason in reduction of organic carbon in high dose of lime application might be due to the excess amount of lime application favoured the condition to escape the ammonia gas or liming increases the soil biological activity, thus favouring the mineralization of organic matter, which ultimately result in $\mathrm{CO}_{2}$ losses and a decrease of the soil organic carbon stocks (Leifeld et al., 2013). Application of different doses of lime with organics increased available nutrient status. 
Table.1 Release of ammonical nitrogen $\left(\mathrm{NH}_{4}+-\mathrm{N}\right)$ and nitrate nitrogen $\left(\mathrm{NO}_{3}-\mathrm{N}\right)$ at different stages as affected by various doses of lime with organics during the incubation period

\begin{tabular}{|c|c|c|c|c|c|c|c|c|c|c|c|c|}
\hline \multirow[b]{2}{*}{ Treatment } & \multicolumn{6}{|c|}{ Release of ammonical nitrogen $\left(\mathrm{NH}_{4}{ }^{+}-\mathrm{N}\right)$} & \multicolumn{6}{|c|}{ Release of nitrate nitrogen $\left(\mathrm{NO}_{3}{ }^{-} \mathrm{N}\right)$} \\
\hline & O DAI & $\begin{array}{l}20 \\
\text { DAI }\end{array}$ & $\begin{array}{l}40 \\
\text { DAI }\end{array}$ & 60 DAI & 80 DAI & $\begin{array}{l}100 \\
\text { DAI }\end{array}$ & O DAI & $\begin{array}{l}20 \\
\text { DAI }\end{array}$ & $\begin{array}{l}40 \\
\text { DAI }\end{array}$ & $\begin{array}{l}60 \\
\text { DAI }\end{array}$ & 80 DAI & 100 DAI \\
\hline $\mathbf{T}_{1}:$ Control (Soil) & $4.99^{\mathrm{e}}$ & $9.88^{\mathrm{i}}$ & $14.70^{\mathrm{i}}$ & $18.79^{\mathrm{i}}$ & $16.85^{\mathrm{h}}$ & $16.67^{\mathrm{i}}$ & $4.813^{\mathrm{f}}$ & $8.753^{\mathrm{i}}$ & $15.41^{\mathrm{i}}$ & $21.74^{j}$ & $25.75^{\mathrm{j}}$ & $30.08^{\mathrm{k}}$ \\
\hline $\mathrm{T}_{2}:$ Lime rate (LR) $\mathbf{1 0 0 \%}$ & $7.25^{\mathrm{a}}$ & $19.95^{\mathrm{f}}$ & $30.47^{\mathrm{f}}$ & $41.52^{f}$ & $35.55^{\mathrm{f}}$ & $31.43^{\mathrm{e}}$ & $5.297^{\mathrm{e}}$ & $14.52^{\text {fg }}$ & $37.73^{\mathrm{ef}}$ & $75.96^{\mathrm{e}}$ & $86.59^{\mathrm{e}}$ & $07.41^{\mathrm{g}}$ \\
\hline $\mathrm{T}_{3}:$ FYM @ 5ton ha ${ }^{-1}$ & $5.10^{\mathrm{e}}$ & $25.66^{\mathrm{c}}$ & $37.27^{\mathrm{d}}$ & $47.26^{\mathrm{e}}$ & $40.34^{\mathrm{de}}$ & $36.35^{\mathrm{d}}$ & $5.373^{\mathrm{e}}$ & ${ }_{h}^{13.53^{g}}$ & $30.63^{\mathrm{h}}$ & $50.63^{i}$ & $55.26^{\mathrm{i}}$ & $68.88^{j}$ \\
\hline $\mathbf{T}_{4}$ : Enriched compost (EC) @ 5ton I & $6.10^{\mathrm{d}}$ & $20.05^{\mathrm{ef}}$ & $24.57^{\mathrm{h}}$ & $38.00^{\mathrm{g}}$ & $26.51^{\mathrm{g}}$ & $22.48^{h}$ & $5.487^{\mathrm{e}}$ & $16.52^{\mathrm{e}}$ & $36.71^{\mathrm{f}}$ & $58.74^{\mathrm{h}}$ & $68.89^{\mathrm{h}}$ & $79.06^{\mathrm{i}}$ \\
\hline T $_{5}:$ LR 100\% + FYM @ 5ton ha ${ }^{-1}$ & $7.37^{\mathrm{a}}$ & $39.83^{\mathrm{a}}$ & $54.05^{\mathrm{a}}$ & $69.86^{\mathrm{a}}$ & $53.33^{\mathrm{a}}$ & $44.17^{\mathrm{a}}$ & $6.443^{b}$ & $20.99^{c}$ & $33.99^{\mathrm{g}}$ & $71.56^{\mathrm{f}}$ & $81.96^{\mathrm{f}}$ & $115.00^{c}$ \\
\hline $\mathrm{T}_{6}: \mathrm{LR} 100 \%$ + EC @ 5ton ha ${ }^{-1}$ & $7.12^{\mathrm{a}}$ & $29.20^{\mathrm{b}}$ & $40.52^{c}$ & $54.78^{c}$ & $44.13^{\mathrm{c}}$ & $37.64^{c}$ & $6.947^{\mathrm{a}}$ & $31.74^{\mathrm{a}}$ & $63.78^{\mathrm{a}}$ & $96.42^{\mathrm{a}}$ & $111.0^{\mathrm{a}}$ & $138.20^{\mathrm{a}}$ \\
\hline T $_{7}:$ LR 50\% + FYM @ 5ton ha ${ }^{-1}$ & $6.90^{\mathrm{ab}}$ & $29.57^{b}$ & $42.78^{b}$ & $63.48^{b}$ & $47.81^{\mathrm{b}}$ & $41.77^{b}$ & $5.857^{\mathrm{d}}$ & $19.96^{\mathrm{c}}$ & $40.17^{\mathrm{d}}$ & $81.74^{\mathrm{d}}$ & $92.39^{c}$ & $103.20^{\mathrm{e}}$ \\
\hline T: LR 50\% + EC @ 5ton ha ${ }^{-1}$ & $6.34^{\mathrm{cd}}$ & $16.79^{\mathrm{h}}$ & $27.19^{g}$ & $48.88^{d}$ & $39.40^{\mathrm{e}}$ & $32.40^{\mathrm{e}}$ & $6.987^{\mathrm{a}}$ & $31.53^{\mathrm{a}}$ & $52.86^{\mathrm{b}}$ & $92.39^{b}$ & $99.30^{b}$ & $121.40^{b}$ \\
\hline T9: LR 25\% + FYM @ 5ton ha ${ }^{-1}$ & $7.12^{\mathrm{a}}$ & $22.81^{d}$ & $31.89^{\mathrm{e}}$ & $54.38^{\mathrm{c}}$ & $41.82^{d}$ & $41.15^{b}$ & $6.453^{b}$ & $12.83^{\mathrm{h}}$ & $\underset{\text { ef }}{39.11^{\mathrm{d}}}$ & $60.77^{\mathrm{h}}$ & $89.21^{\mathrm{d}}$ & $98.47^{\mathrm{g}}$ \\
\hline $\mathrm{T}_{10}: \mathrm{LR} 25 \%$ + EC @ 5ton ha ${ }^{-1}$ & $6.62^{b c}$ & $21.45^{\mathrm{e}}$ & $26.71^{\mathrm{g}}$ & $46.54^{\mathrm{e}}$ & $35.00^{f}$ & $24.92^{\mathrm{g}}$ & $6.28^{\mathrm{bc}}$ & $14.93^{\mathrm{f}}$ & $45.34^{\mathrm{c}}$ & $83.86^{\mathrm{c}}$ & $90.40 d$ & $112.60^{\mathrm{d}}$ \\
\hline T $_{11}:$ LR 10\% + FYM @ 5ton ha ${ }^{-1}$ & $6.89^{\mathrm{ab}}$ & $22.88^{d}$ & $29.74^{\mathrm{f}}$ & $37.90^{\mathrm{g}}$ & $40.47^{\mathrm{de}}$ & $27.00^{f}$ & $\begin{array}{l}6.967^{\mathrm{c}} \\
\mathrm{d}\end{array}$ & $24.78^{b}$ & $37.28^{f}$ & $52.59^{\mathrm{i}}$ & $79.00^{\mathrm{g}}$ & $100.80^{f}$ \\
\hline $\mathrm{T}_{12}:$ LR 10\% + EC @ 5ton ha ${ }^{-1}$ & $6.49^{\text {bcd }}$ & $18.58^{\mathrm{g}}$ & $24.70^{\mathrm{h}}$ & $35.63^{h}$ & $35.31^{\mathrm{f}}$ & $21.89^{h}$ & $6.517^{b}$ & $18.56^{\mathrm{d}}$ & $41.12^{\mathrm{d}}$ & $67.25^{\mathrm{g}}$ & $87.74^{\mathrm{e}}$ & $85.00^{\mathrm{h}}$ \\
\hline LSD (0.05) & 0.442 & 1.200 & 1.135 & 1.609 & 1.862 & 1.261 & 0.362 & 1.122 & 2.391 & 2.037 & 1.458 & 2.066 \\
\hline CV (\%) & 4.000 & 3.060 & 2.090 & 2.050 & 2.890 & 2.360 & $4.813^{f}$ & $8.753^{i}$ & $15.41^{\mathrm{i}}$ & $21.74^{j}$ & $25.75^{j}$ & $30.08^{k}$ \\
\hline $\operatorname{Sem}( \pm)$ & 0.151 & 0.409 & 0.380 & 0.549 & 0.635 & 0.438 & $5.297^{\mathrm{e}}$ & $14.52^{\text {fg }}$ & $37.73^{\mathrm{ef}}$ & $75.96^{e}$ & $86.59^{\mathrm{e}}$ & $07.41^{\mathrm{g}}$ \\
\hline
\end{tabular}

*Values followed by similar alphabet are not significantly different at $\alpha=5 \%$ as per Duncan multiple range test

$* \mathrm{LR}=$ Lime rate, $\mathrm{FYM}=$ Farm yard manure, $\mathrm{EC}=$ Enriched compost

$* \mathrm{LSD}=$ Least significant difference, $\mathrm{CV}=\mathrm{Co}$-efficient of variation, $\mathrm{SeM}=$ Standard error of mean 
Table.2 Parameter estimated according to the first order single compartment model for nitrogen mineralization in soil

\begin{tabular}{|c|c|c|c|c|c|c|}
\hline Treatments & $k \times 10-2(/$ day $)$ & $\mathbf{N}$ cumulative & No $(\mathbf{p p m})$ & $k / \mathrm{No}(\mathbf{x 1 0}-5)$ & $\mathbf{N}_{\text {mineral nitrogen }}$ & $R^{2}$ \\
\hline $\mathbf{T}_{1}:$ Control (Soil) & $2.80^{\mathrm{e}}$ & $188.70^{\mathrm{K}}$ & $200.90^{\mathrm{k}}$ & $13.95^{\mathrm{a}}$ & $188.70^{\mathrm{K}}$ & 0.867 \\
\hline$T_{2}:$ Lime rate (LR) $100 \%$ & $3.50^{\mathrm{b}}$ & $483.70^{f}$ & $498.80^{f}$ & $7.018^{d}$ & $468.40^{f}$ & 0.847 \\
\hline $\mathrm{T}_{3}:$ FYM @ 5ton ha ${ }^{-1}$ & $3.43^{\mathrm{c}}$ & $415.50^{\mathrm{i}}$ & $429.40 \mathrm{i}$ & $8.00^{\mathrm{b}}$ & $403.30^{\mathrm{i}}$ & 0.764 \\
\hline $\mathrm{T}_{4}$ : Enriched compost (EC) @ 5ton & $3.40^{\mathrm{c}}$ & $403.90^{j}$ & $417.90^{j}$ & $8.14^{\mathrm{b}}$ & $392.40^{\mathrm{j}}$ & 0.798 \\
\hline T5: LR 100\% + FYM @ 5ton ha ${ }^{-1}$ & $3.50^{\mathrm{b}}$ & $598.60^{b}$ & $617.20^{\mathrm{b}}$ & $5.67^{\mathrm{g}}$ & $579.70^{b}$ & 0.767 \\
\hline $\mathrm{T}_{6}:$ LR 100\% + EC @ 5ton ha ${ }^{-1}$ & $3.60^{\mathrm{a}}$ & $661.50^{\mathrm{a}}$ & $680.00^{\mathrm{a}}$ & $5.29^{\mathrm{h}}$ & $638.70^{\mathrm{a}}$ & 0.773 \\
\hline T $_{7}:$ LR 50\% + FYM @ 5ton ha ${ }^{-1}$ & $3.60^{\mathrm{a}}$ & $575.60^{c}$ & $591.80^{c}$ & $6.08^{\mathrm{f}}$ & $555.80^{c}$ & 0.782 \\
\hline T.: LR 50\% + EC @ 5ton ha ${ }^{-1}$ & $3.60^{\mathrm{a}}$ & $575.50^{c}$ & $591.70^{c}$ & $6.09^{f}$ & $555.70^{\mathrm{c}}$ & 0.813 \\
\hline T9: LR 25\% + FYM @ 5ton ha ${ }^{-1}$ & $3.50^{\mathrm{b}}$ & $506.00^{\mathrm{e}}$ & $521.80^{\mathrm{e}}$ & $6.71^{\mathrm{e}}$ & $490.00^{\mathrm{e}}$ & 0.870 \\
\hline $\mathrm{T}_{10}:$ LR 25\% + EC @ 5ton ha ${ }^{-1}$ & $3.57^{\mathrm{a}}$ & $514.70^{\mathrm{d}}$ & $529.60^{\mathrm{d}}$ & $6.74^{\mathrm{e}}$ & $497.40^{\mathrm{d}}$ & 0.837 \\
\hline T $_{11}:$ LR 10\% + FYM @ 5ton ha ${ }^{-1}$ & $3.33^{\mathrm{d}}$ & $465.30^{\mathrm{g}}$ & $482.50^{\mathrm{g}}$ & $6.91^{\mathrm{de}}$ & $453.20^{\mathrm{g}}$ & 0.839 \\
\hline T $_{12}:$ LR 10\% + EC @ 5ton ha ${ }^{-1}$ & $3.40^{\mathrm{c}}$ & $448.80^{\mathrm{h}}$ & $464.30^{\mathrm{h}}$ & $7.32^{\mathrm{c}}$ & $436.00^{\mathrm{h}}$ & 0.816 \\
\hline $\operatorname{LSD}(\alpha=0.05)$ & 0.05 & 4.59 & 4.92 & 0.26 & 4.62 & -- \\
\hline CV $(\%)$ & 0.02 & 1.57 & 1.68 & 0.09 & 1.57 & -- \\
\hline $\operatorname{Sem}( \pm)$ & 0.87 & 0.56 & 0.58 & 2.1 & 0.58 & -- \\
\hline
\end{tabular}

$* \mathrm{~N}_{0}$ is the potential mineralizable Nitrogen; $k$ is the mineralization rate constant; $k / \mathrm{N}_{0}$ is the absolute rate constant; $\mathrm{R}^{2}$ is the range coefficient

*Means with at least one similar lower-case letters within a column are not significantly different as per Duncan multiple range test at LSD (P<0.05)

* $\mathrm{LSD}=$ Least significant difference, $\mathrm{CV}=\mathrm{Co}$-efficient of variation, $\mathrm{SeM}=$ Standard error of mean

$* \mathrm{LR}=$ Lime rate, $\mathrm{FYM}=$ Farm yard manure, $\mathrm{EC}=$ Enriched compost 
Table.3 Change in rate of mineralizable nitrogen $(\mathrm{dN} / \mathrm{dt})$ with respect to incubation periods

\begin{tabular}{|c|c|c|c|c|c|c|}
\hline \multirow[t]{2}{*}{ Treatments } & \multicolumn{6}{|c|}{ Rate of mineralizable nitrogen $(d N / d t)\left(\mathrm{mg} \cdot \mathrm{kg}^{-1} \cdot \mathrm{day}^{-1}\right)$} \\
\hline & 0 DAI & $20 \mathrm{DAI}$ & $40 \mathrm{DAI}$ & $60 \mathrm{DAI}$ & $80 \mathrm{DAI}$ & $100 \mathrm{DAI}$ \\
\hline $\mathbf{T}_{1}:$ Control (Soil) & $5.63^{\mathrm{k}}$ & $3.21^{\mathrm{k}}$ & $1.84^{\mathrm{j}}$ & $1.05^{\mathrm{i}}$ & $.599^{\mathrm{k}}$ & $.342^{\mathrm{j}}$ \\
\hline$T_{2}:$ Lime rate (LR) $100 \%$ & $17.46^{\mathrm{f}}$ & $8.67^{\mathrm{f}}$ & $4.31^{\mathrm{e}}$ & $2.14^{\mathrm{f}}$ & $1.06^{\mathrm{g}}$ & $.527^{\mathrm{g}}$ \\
\hline T $_{3}:$ FYM @ 5ton ha ${ }^{-1}$ & $14.74^{\mathrm{i}}$ & $7.42^{i}$ & $3.73^{\mathrm{h}}$ & $1.88^{\mathrm{h}}$ & $0.946^{\mathrm{i}}$ & $.476^{\mathrm{h}}$ \\
\hline $\mathrm{T}_{4}:$ Enriched compost (EC) @ 5ton ha ${ }^{-1}$ & $14.21^{\mathrm{j}}$ & $7.20^{j}$ & $3.65^{\mathrm{i}}$ & $1.85^{\mathrm{h}}$ & $.936^{\mathrm{j}}$ & $.474^{\mathrm{i}}$ \\
\hline T $_{5}:$ LR 100\% + FYM @ 5ton ha ${ }^{-1}$ & $21.60^{b}$ & $10.73^{b}$ & $5.33^{\mathrm{b}}$ & $2.65^{b}$ & $1.31^{\mathrm{b}}$ & $.652^{\mathrm{b}}$ \\
\hline $\mathrm{T}_{6}:$ LR 100\% + EC @ 5ton ha-1 & $24.48^{\mathrm{a}}$ & $11.92^{\mathrm{a}}$ & $5.80^{\mathrm{a}}$ & $2.82^{\mathrm{a}}$ & $1.37^{\mathrm{a}}$ & $.669^{\mathrm{a}}$ \\
\hline T $_{7}:$ LR 50\% + FYM @ 5ton ha ${ }^{-1}$ & $21.30^{\mathrm{c}}$ & $10.37^{\mathrm{c}}$ & $5.05^{\mathrm{c}}$ & $2.46^{\mathrm{c}}$ & $1.20^{\mathrm{c}}$ & $.582^{\mathrm{c}}$ \\
\hline T8: LR 50\% + EC @ 5ton ha ${ }^{-1}$ & $21.30^{c}$ & $10.37^{\mathrm{c}}$ & $5.05^{\mathrm{c}}$ & $2.46^{\mathrm{c}}$ & $1.20^{\mathrm{c}}$ & $.582^{c}$ \\
\hline T9: LR 25\% + FYM @ 5ton ha ${ }^{-1}$ & $18.26^{\mathrm{e}}$ & $9.07^{\mathrm{e}}$ & $4.50^{\mathrm{d}}$ & $2.24^{\mathrm{d}}$ & $1.11^{\mathrm{e}}$ & $.552^{\mathrm{e}}$ \\
\hline $\mathrm{T}_{10}:$ LR 25\% + EC @ 5ton ha ${ }^{-1}$ & $18.89^{d}$ & $9.26^{\mathrm{d}}$ & $4.54^{d}$ & $2.22^{\mathrm{de}}$ & $1.09^{\mathrm{f}}$ & $.534^{\mathrm{f}}$ \\
\hline T $_{11}:$ LR 10\% + FYM @ 5ton ha ${ }^{-1}$ & $16.08^{\mathrm{g}}$ & $8.26^{\mathrm{g}}$ & $4.24^{\mathrm{f}}$ & $2.18^{\text {ef }}$ & $1.12^{\mathrm{d}}$ & $.574^{\mathrm{d}}$ \\
\hline T $_{12}:$ LR 10\% + EC @ 5ton ha ${ }^{-1}$ & $15.79^{\mathrm{h}}$ & $8.00^{\mathrm{h}}$ & $4.05^{\mathrm{g}}$ & $2.05^{\mathrm{g}}$ & $1.04^{\mathrm{h}}$ & $.527^{\mathrm{g}}$ \\
\hline $\operatorname{LSD}(\alpha=0.05)$ & 0.26 & 0.08 & 0.05 & 0.05 & 0.001 & 0.002 \\
\hline $\mathrm{CV}(\%)$ & 0.09 & 0.03 & 0.02 & 0.02 & 0.001 & 0.002 \\
\hline $\operatorname{Sem}( \pm)$ & 0.86 & 0.56 & 0.73 & 1.2 & 1.75 & 2.32 \\
\hline
\end{tabular}

*DAI- Days after incubation

*Values followed by similar alphabet are not significantly different at $\alpha=5 \%$ as per Duncan multiple range test

$* \mathrm{LSD}=$ Least significant difference, $\mathrm{CV}=\mathrm{Co}$-efficient of variation, $\mathrm{SeM}=$ Standard error of mean

$*$ LR $=$ Lime rate, FYM = Farm yard manure, EC = Enriched compost 
Table.4 Soil properties after incubation of soil for estimating N-mineralization

\begin{tabular}{|c|c|c|c|c|c|c|}
\hline Treatment & pH & $\mathbf{E C}$ & $\begin{array}{l}\text { OC } \\
(\%)\end{array}$ & $\begin{array}{l}\text { Av. N } \\
\left.\text { (kg.ha }^{-1}\right)\end{array}$ & $\begin{array}{l}\text { Av. } P_{2} O_{5} \\
\left(k^{\prime} \cdot h^{-1}\right)^{-1}\end{array}$ & $\begin{array}{l}\text { Av. } K_{2} 0 \\
\text { (kg/ha) }\end{array}$ \\
\hline $\mathbf{T}_{1}:$ Control (Soil) & $5.53^{d}$ & $0.69^{b c}$ & $0.69^{f}$ & $229.00^{\mathrm{k}}$ & $9.14^{\mathrm{i}}$ & $204.50^{\mathrm{h}}$ \\
\hline $\mathrm{T}_{2}:$ Lime rate (LR) $100 \%$ & $6.40^{\mathrm{a}}$ & $0.57^{\mathrm{def}}$ & $1.00^{\mathrm{e}}$ & $321.70^{\mathrm{j}}$ & $10.78^{h}$ & $281.00^{\mathrm{g}}$ \\
\hline T $_{3}:$ FYM @ 5ton ha ${ }^{-1}$ & $4.00^{\mathrm{j}}$ & $0.44^{\text {ghi }}$ & $1.23^{\mathrm{d}}$ & $324.10^{\mathrm{i}}$ & $10.32^{\mathrm{h}}$ & $325.10^{\mathrm{a}}$ \\
\hline $\mathrm{T}_{4}:$ Enriched compost (EC) @ 5ton $\mathrm{ha}^{-1}$ & $5.43^{\mathrm{e}}$ & $0.75^{\mathrm{ab}}$ & $1.30^{\mathrm{b}}$ & $333.30^{\mathrm{h}}$ & $16.68^{\mathrm{e}}$ & $313.60^{d}$ \\
\hline T $_{5}:$ LR 100\% + FYM @ 5ton ha ${ }^{-1}$ & $6.20^{\mathrm{b}}$ & $0.81^{\mathrm{a}}$ & $1.18^{\mathrm{d}}$ & $411.80^{f}$ & $15.27^{f}$ & $309.00^{\mathrm{e}}$ \\
\hline T$_{6}:$ LR 100\% + EC @ 5ton ha ${ }^{-1}$ & $6.43^{\mathrm{a}}$ & $0.51^{\text {efgh }}$ & $1.32^{\mathrm{ab}}$ & $432.60^{c}$ & $29.05^{\mathrm{a}}$ & $304.50^{\mathrm{f}}$ \\
\hline T $:$ LR 50\% + FYM @ 5ton ha ${ }^{-1}$ & $5.53^{\mathrm{d}}$ & $0.49^{\text {fghi }}$ & $1.29^{b}$ & $409.50^{\mathrm{g}}$ & $16.77^{\mathrm{e}}$ & $312.10^{\mathrm{d}}$ \\
\hline T8: LR 50\% + EC @ 5ton ha ${ }^{-1}$ & $5.93^{\mathrm{c}}$ & $0.41^{\mathrm{hi}}$ & $1.33^{\mathrm{ab}}$ & $415.80^{\mathrm{e}}$ & $25.84^{\mathrm{b}}$ & $316.80^{c}$ \\
\hline T $_{9}:$ LR 25\% + FYM @ 5ton ha ${ }^{-1}$ & $4.90^{\mathrm{g}}$ & $0.53 \mathrm{~d}^{\mathrm{efg}}$ & $1.24^{\mathrm{c}}$ & $420.30^{\mathrm{d}}$ & $19.00^{d}$ & $321.50^{b}$ \\
\hline T $_{10}:$ LR 25\% + EC @ 5ton ha ${ }^{-1}$ & $5.00^{\mathrm{f}}$ & $0.59^{\mathrm{de}}$ & $1.37^{\mathrm{a}}$ & $446.90^{\mathrm{a}}$ & $22.85^{\mathrm{c}}$ & $323.50^{\mathrm{a}}$ \\
\hline T $_{11}:$ LR 10\% + FYM @ 5ton ha ${ }^{-1}$ & $4.20^{\mathrm{i}}$ & $0.62^{\text {cd }}$ & $1.12^{\mathrm{d}}$ & $415.70^{\mathrm{e}}$ & $11.87^{\mathrm{g}}$ & $304.80^{f}$ \\
\hline T12: LR10\% + EC @ 5ton ha ${ }^{-1}$ & $4.43^{\mathrm{h}}$ & $0.40^{\mathrm{i}}$ & $1.13^{\mathrm{d}}$ & $439.60^{b}$ & $18.91^{\mathrm{d}}$ & $316.00^{c}$ \\
\hline $\operatorname{LSD}(\alpha=0.05)$ & 0.05 & 0.09 & 0.054 & 1.01 & 0.56 & 1.71 \\
\hline $\mathrm{CV}(\%)$ & 0.67 & 9.19 & 2.14 & 0.16 & 1.91 & 0.33 \\
\hline $\operatorname{Sem}( \pm)$ & 0.02 & 0.03 & 0.02 & 0.35 & 0.19 & 0.58 \\
\hline
\end{tabular}

*Values followed by similar alphabet are not significantly different at $\alpha=5 \%$ as per Duncan multiple range test

* $\mathrm{LSD}=$ Least significant difference, $\mathrm{CV}=\mathrm{Co}$-efficient of variation, $\mathrm{SeM}=$ Standard error of mean

$* \mathrm{LR}=$ Lime rate, $\mathrm{FYM}=$ Farm yard manure, $\mathrm{EC}=$ Enriched compost 
Fig.1 Change in mineralization of ammonical nitrogen $\left(\mathrm{NH}_{4}+-\mathrm{N}\right)\left(\mathrm{g} \cdot \mathrm{kg}^{-1}\right.$.day $\left.{ }^{-1}\right)$ with respect to incubation period (DAI $=$ Days after incubation)

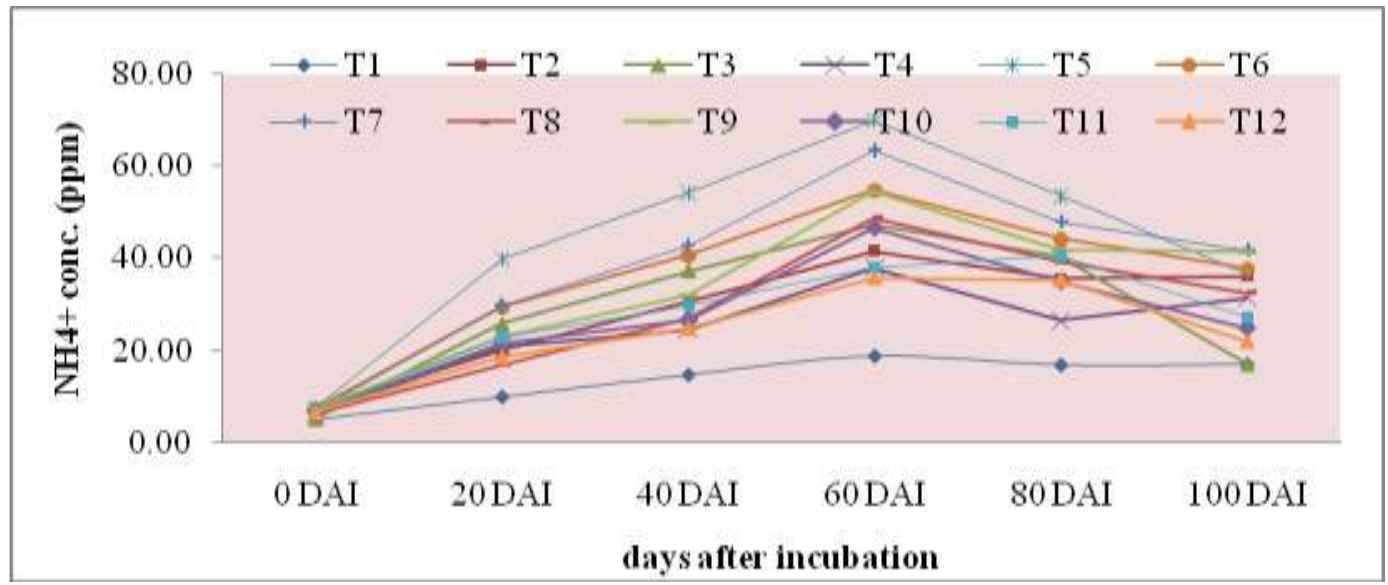

Fig.2 Change in mineralization of nitrate nitrogen $\left(\mathrm{NO}_{3}^{--\mathrm{N}}\right)\left(\mathrm{g} \cdot \mathrm{kg}^{-1} \cdot \mathrm{day}{ }^{-1}\right)$ with respect to incubation period (DAI= Days after incubation)

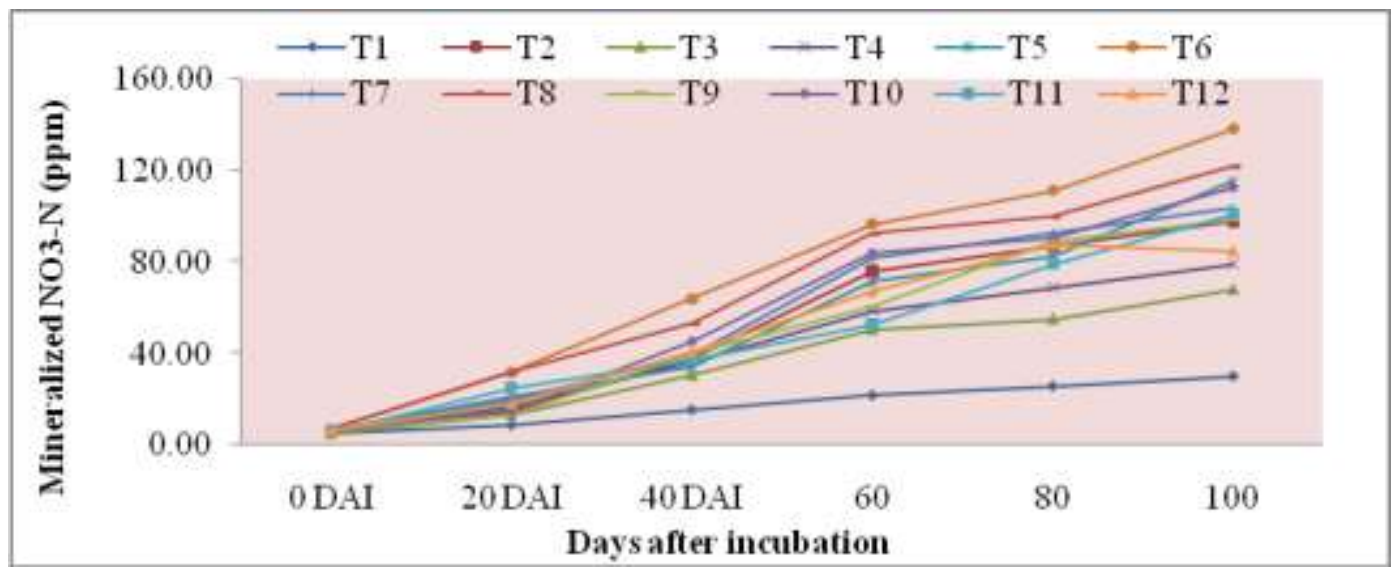

Fig.3 Change in rate of mineralizable nitrogen $(\mathrm{dN} / \mathrm{dt})\left(\mathrm{g} \cdot \mathrm{kg}^{-1}\right.$.day $\left.{ }^{-1}\right)$ with respect to incubation periods (DAI $=$ Days after incubation)

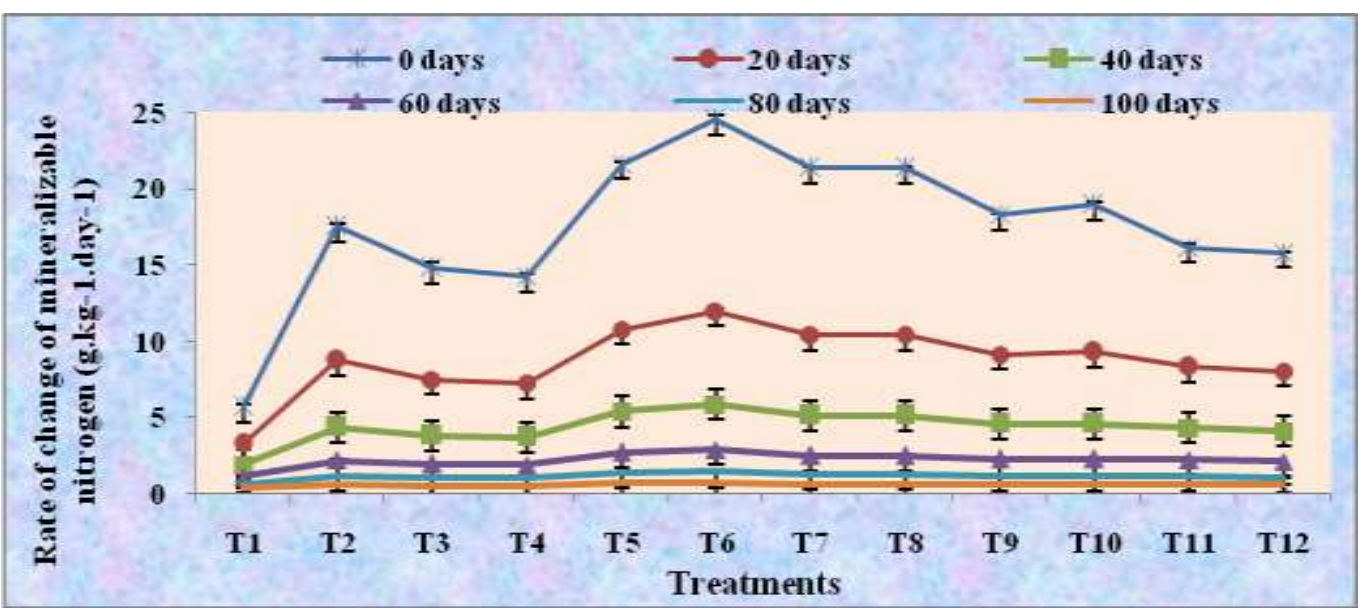


Highest available nitrogen was found in $25 \%$ of recommended lime dose with organics than $100 \%$ of recommended lime dose. The reason in reduction of organic carbon in high dose of lime application might be due to the excess amount of lime application favoured the condition to escape the ammonia gas which reduce the availability of nitrogen in soil (Donald, 2011). Moreover available nitrogen content also varied with type of organics. In case of similar dose of lime application, higher available nitrogen was found in enriched compost treated soil samples than FYM treated samples. It might be due to initial nutritional status of the manures and their decomposition pattern.

Moreover liming in the acid soils raises soil $\mathrm{pH}$, which in turn releases phosphate ions precipitated with $\mathrm{Al}$ and $\mathrm{Fe}$ ions thus making $P$ available for plant uptake (Chimdi et al., 2012). When lime combined with manure it may even provide more favourable environment for microbial activities and possibly result in net mineralization of soil organic phosphorus.

The present investigation indicated that the application of lime with different composts tend to increased soil available potassium after incubation. This might be due to calcium replaces the potassium from exchange complex releasing potassium to the solution phase and increased the available potassium content in the soil.

Furthermore, manure is known by its ability of improving soil physical properties such as structure which in turn improves soil moisture, microbial activity and makes nutrients available (Otieno et al., 2007). The use of manure and lime and its effects in enhancing available nutrient content has been reported elsewhere by several other researchers (Schmidt et al., 2001; Javaid and Mahmood, 2010; Devi et al., 2013).
In conclusion, from the experiment, it was found that the first-order exponential model could fit well with the observed nitrogen mineralization data of all treatments. In case of $\mathrm{N}$-mineralization, it was observed that lime rate and co-application of organic amendment has increased $\mathrm{N}$-mineralization rate. Based on the results, it can be concluded that enriched compost with lime has a better effect on nitrogen mineralization kinetics than FYM with lime. Therefore, integrated use of lime and organics might have considerable positive influence on both ammonical and nitrate nitrogen availability, influence on $\mathrm{N}$ mineralization rate as well as use efficiency in acidic soils.

\section{References}

Alexander, M. 1980. Effects of acidity on microorganisms and microbial processes in soil. In: Introduction to soil microbiology. In. Wiley, J. and Sons (eds.). New York, pp. 363-374.

Antonopoulos, A.Z. 1999. Comparison of different models to simulate soil temperature and moisture effects on nitrogen mineralization in the soil. $J$. Plant Nutr. Soil Sci. 162: 667-675.

Bartholomew, W.V. and Clark, F.E. 2011. Soil nitrogen mineralization. Amer. Soc. Agron. 10: 96-99.

Bhatt, Z.A., Padder, S.A and Ganai, A.Q. 2017. Modeling nitrogen mineralization kinetics in soils treated with farm yard manure (fym). Int. J. Adv. Sci. Engg. Tech. (ISSN). 5: 2321-9009.

Biswas, S.S., Singhal, S.K., Biswas, D.R., Singh, R.D., Roy, T., Sarkar, A., Ghosh, A. and Das, D. 2017. Synchronization of nitrogen supply with demand by wheat using sewage sludge as organic amendment in an inceptisol. J. Ind. Soc. Soil Sci. 65: 264-273.

Blake, G.R. and Hartge, K.H. 1986. Bulk density. In: Methods of Soil Analysis. 
Part I -Physical and Mineralogical Methods. Second edition. Klute, A. (ed.). Am. Soc. Agron., Madison WI.

Chimdi, A., Gebrekidan, V., Kibret, K. and Tadesse, A. 2012. Effects of liming on acidity related chemical properties of soils of different land use systems in Western Oromia, Ethiopia. World J. Agric. Sci. 8(6): 560-567.

Deng, S.P. and Tabatabai, M.A. 2000. Effect of cropping systems on nitrogen mineralization in soils. Biol. Fertil. Soils. 31: 211-218.

Devi, K.N., Singh, T.B., Athokpam, H.S., Singh, N.B. and Shamurailatpam, D. 2013. Influence of inorganic, biological and organic manures on nodulation and yield of soybean (Glycine max (L.) Merrill) and soil properties. Aus. J. Crop Sci. 7(9): 1407-1415.

Donald, B. 2011. Soil pH: What it means. State University of New York College of Environmental Science and Forestry. http://www.esf.edu. Retrieved on $21^{\text {st }}$ Dec 2017.

Edmeades, D.C., Judd, M. and Sarathchandra, S. U. 1981. The effect of lime on nitrogen mineralization as measured by grass growth. Plant and Soil. 60: 177186.

Gonzalez-Prieto, S.J., Carballas, M., Villar, M.C. and Carballas, T. 1995. Organic nitrogen mineralization in temperate humid-zone soils after 2 and 6 weeks of aerobic incubation. Biol. Fert. Soils. 20: 237-242.

Griffin, T.S. 2008. Nitrogen availability. In. Schepers, J.S. and Raun, W.R. (eds.) Nitrogen in agricultural soils. Agron. Monogr. ASA, CSSA, SSSA, Madison WI, pp. 616-646.

Haynes, R.J. 1998. Lime and phosphate in the soil-plant system. Adv. Agron. 37: 249315.

Jackson, M.L. 1973. Soil Chemical Analysis. Prentice Hall of India Pvt. Ltd., New
Delhi, India, pp. 173-175.

Javaid, A. and Mahmood, N. 2010. Growth, nodulation and yield response of soybean to biofertilizers and organic manures. Pakistan J. Bot. 42(2): 863871.

Leifeld, J., Bassin, S., Conen, F., Hajdas, I., Egli, M. and Fuher, J. 2013. Control of soil $\mathrm{pH}$ on turnover of belowground organic matter in subalpine grassland. Biogeochemistry. 112: 59-69.

Matus, F.J., Lusk, C.H. and Maire, C.R. 2008. Effects of soil texture, carbon input rates, and little quality on free organic matter and nitrogen mineralization in Chilean rain forest and agricultural soils. Comm. Soil Sci. Plant Anal. 39: 187-201.

Moharana, P.C., Biswas, D.R. and Datta, S.C. 2015. Mineralization of nitrogen, phosphorus and sulphur in soil as influenced by rock phosphate enriched compost and chemical fertilizers. J. Ind. Soc. Soil Sci. 63: 283-293.

Murugan, A.V. and Swarnam, T.P. 2013. Nitrogen release pattern from organic manures applied to an acid soil. J. Agril. Sci. 5: 174-184.

Okur, N., Kaykcoglu, H.H., Okur, B. and Delibacak, B. 2008. Organic amendment based tobacco waste compost and farmyard manure: influence on soil biological properties and butter-head lettuce yield. Turkish J. Agric. Forest., 32(2): 91-99.

Onken, A.B. and Sunderman, H.D. 1977. Colorimetric determination of exchangeable ammonium, urea, nitrate and nitrite in a single soil extract. Agron. J. 69: 49-58.

Otieno, P.E., Muthomi, J.W., Chemining'wa, G.N. and Nderitu, J. 2007. Effects of rhizobia inoculation, farm yard manure and nitrogen fertilizer on growth, nodulation and yield of selected food grain legumes. Afr. Crop Sci. 
Conference Proc. 8: 305-312.

Patil, R.G. 1990. Mineralizationimmobilization of nitrogen as influenced by green manure and urea in straw amended soils. Ph.D. Thesis, Indian Agricultural Research Institute, New Delhi.

Power, J.F. and Papendick, R.I. 1985. Organic sources of nitrogen. In. Fertilizer technology and use. Engelstad, O.P. (ed.). Soil Sci. Soc. Ame. Madison, Wisconsin, USA, pp. 503-520.

Saha, S., Mina, B.L., Gopinath, K.A., Kundu, S. and Gupta, H.S. 2008. Organic amendments affect biochemical properties of a sub-temperature soil of the Indian Himalayas. Nutrient Cycling in Agroecosystems. 80(3): 233-242.

Schmidt, J.P., Lamb, J.A., Schimitt, M.A., Randall, G.W., Orf, J.H. and Gollan, H.I. 2001. Soybean varietal response to liquid swine manure application. Agron. J. 93: 358-363.

Senwo, Z.N. and Tabatabai, M.A. 2005. Effect of management systems on nitrogen mineralization and nitrification in soils. Comm. Soil Sci. Plant Anal. 36: 1313-1326.

Sims, J. T. 1996. Lime requirement. In Methods of Soil Analysis, part 3. Soil Sci. Soc.of America Book Series No. 5, Sparks, D.L. (ed.) pp. 491-515.

Stanford, G. and Epstein, E. 1974. Nitrogen mineralization-water relations in soils. Soil Sci. Soc. Am. Proc. 38: 103-107.

Stanford, G. and S.J. Smith. 1972. Nitrogen minerialization potentials of soils. Soil Sci. Soc. Am. Proc. 36: 465-472.

Stanford, G., Frere, M.H. and Schwaninger, D.H. 1973. Temperature coefficient of soil nitrogen mineralization. Soil Sci. 115: $121-123$.

Vadivelu, T.K., Sen, B.P., Bhaskar, U., Baruah, D., Sarkar, A.K., Maji K. and Gajbhie K.S. 2004. Soil series of Assam, NBSS publ. No. 101, NBSS and LUP, Nagpur, pp. 229.

Zibilske, L.M. and Bradford, J.M. 2007. Oxygen effects on carbon, polyphenols, and nitrogen mineralization potential in soil. Soil Sci. Soc. Am. J. 71: 133-139.

\section{How to cite this article:}

Lekhika Borgohain, Danish Tamuly, Niloy Borah, Samiran Dutta, Dhruba Jyoti Nath, Ramani kanta Thakuria, Karishma Borah and Sarat Shekhar Bora. 2019. Kinetics of Nitrogen Mineralization as Influenced by Liming and Organic Amendments: A Laboratory Study. Int.J.Curr.Microbiol.App.Sci. 8(01): 853-865. doi: https://doi.org/10.20546/ijcmas.2019.801.093 